\title{
Research on the Obstacles and Counter Measures of Mobile Payment in Short-Term Inbound Tourism
}

\author{
Rong Qiu ${ }^{1, *}$ Khonkhlong Suppakorn ${ }^{2}$
}

\begin{abstract}
${ }^{1}$ Western Modernization Research Center of Guizhou University of Finance and Economics, Guiyang, Guizhou, China ${ }^{2}$ School of Sinology, Mae Fah Luang University, Muang, Chiang Rai 57100, Thailand

*Corresponding author. Email:1147368383@qq.com
\end{abstract}

\begin{abstract}
China's mobile payment scale is in the forefront of the world. While the short-term inbound travel is growing, the advantages of mobile payment are not fully exploited. On the basis of comparing the different countries' means of mobile payment, including the United States, this paper considers that short-term inbound mobile payment affected by consumption habits, inadequate connection of financial policies and financial business between countries. Then, the paper puts forward the suggestions about it.
\end{abstract}

\section{Keywords: short term inbound tourism, mobile payment, financial policy}

\section{INTRODUCTION}

During the recent trip to Thailand, scholars from the two countries conducted extensive exchanges around "Thailand 4.0" and "Made in China 2025" and introduced "the Belt and Road" and "Lancang-Mekong sub-regional economic cooperation" in depth. During this period, some Thai scholars mentioned the difficulty of mobile payment for short-term inbound travel to China. Payment is the last link of value realization. No matter how grand strategies, plans and initiatives are, payment is indispensable in the end. In China, twodimensional code is hung on the shoulder pole of the vegetable market aunts. China's mobile payment is well-known internationally, and also provides great convenience for Chinese outbound travel. Why is such a widely used mobile payment a problem for inbound tourists?

\section{DEVELOPMENT TREND OF INBOUND TOURISM IN CHINA}

Since the reform and opening up, China's inbound tourism probably has gone through three stages. The first stage (1978-2007) is the period of great development of inbound tourism. The general policy of development is "vigorously develop inbound tourism, actively develop domestic tourism and moderately develop outbound tourism". In the second stage (2008-

\footnotetext{
*Project: This paper is one of the research results of the joint fund project of Guizhou University of Finance and Economics and the Ministry Commerce of the PRC. Project Name: "A study on international capital flows of the transition countries under the Impossible Triangle of Mondale". The Project Leader: Qiu Rong. Project No.: 2017SWBZD07.
}

2016), the growth rate of inbound tourism slowed down relatively. During this period, China proposed to vigorously develop domestic tourism, actively develop inbound tourism and orderly develop outbound tourism. In 2016, UNWTO released the global top ten ranking of inbound overnight tourists, which are France, Spain, the United States, China, Italy, the United Kingdom, Germany, Mexico, Thailand and Turkey. On the whole, China's overall ranking has basically stabilized in the third or fourth place in the world in the past decade, and can maintain relatively stable development. The third stage is from 2017. China's inbound tourism has picked up since the financial crisis in 2008, and shows a steady growth trend.

In 2017, China received 139.4824 million inbound tourists, a year-on-year increase of $0.80 \%$, and the total scale reached a record high. Among them, the scale and growth rate of the inbound tourism market for foreigners were 29.1653 million and $3.60 \%$, and the total scale also reached a record high. The mainland (mainland) received 110.3171 million tourists from Hong Kong, Macao and Taiwan, and the total scale also reached a record high. In 2017, China's foreign exchange income from inbound tourism reached US $\$ 123.417$ billion, an increase of $2.90 \%$ year-on-year, and continued to maintain a good momentum of steady growth. Among it, foreign tourists spent 69.547 billion US dollars in China, an increase of $4.1 \%$ year on year, maintaining a good momentum of steady growth. In the first half of 2018, the number of inbound tourists reached 69.23 million, down $0.4 \%$ year on year. And China received 14.82 million foreign tourists, up $4.0 \%$ year on year. Hong Kong, Macao and Taiwan were still the main force of the inbound tourism markets of the mainland, accounting for $78.59 \%$ of the total market 
share. In the first half of 2018, international tourism revenue reached US $\$ 61.8$ billion, and it was $2.8 \%$ higher than the same period of last year. Among them:foreigners spent 35.4 billion US dollars in China, up 4.6\%; Hong Kong compatriots spent 14.2 billion US dollars in the mainland, down $2.5 \%$; Macao compatriots spent 4.2 billion US dollars in the mainland, up 4.2\%; Taiwan compatriots spent 7.9 billion US dollars in the mainland, up $4.2 \%$. ("Table I")

TABLE I. BASIC INFORMATION OF INBOUND TOURISTS AND TOURISM INCOME IN 2017 AND THE FIRST HALF OF 2018

\begin{tabular}{|l|l|l|l|l|l|l|l|}
\hline Year & $\begin{array}{c}\text { the person- } \\
\text { time of } \\
\text { inbound } \\
\text { tourism (ten } \\
\text { thousand) }\end{array}$ & increase $(\%)$ & $\begin{array}{c}\text { the person-time } \\
\text { of foreigner } \\
\text { inbound } \\
\text { tourism(ten } \\
\text { thousand) }\end{array}$ & $\begin{array}{c}\text { increase }(\%) \\
\text { the person-time } \\
\text { of inbound } \\
\text { tourism of Hong } \\
\text { Kong, Macao } \\
\text { and Taiwan(ten } \\
\text { thousand) }\end{array}$ & $\begin{array}{c}\text { increase (\%) } \\
\text { exchange } \\
\text { income from } \\
\text { inbound } \\
\text { tourism(100 } \\
\text { million dollars) }\end{array}$ & $\begin{array}{c}\text { increase } \\
(\%)\end{array}$ \\
\hline 2017 & 13948.24 & 0.80 & 2916.53 & 3.6 & 11031.71 & 2.90 \\
\hline $\begin{array}{l}2018 \\
\text { first } \\
\text { half) }\end{array}$ & 6923 & -0.4 & 1482 & 4.0 & 5441 & 618 \\
\hline
\end{tabular}

a. Data from "Annual Report of China Inbound Tourism Development 2018", China Tourism Academy 2018-07-01

Judging from the structural characteristics of inbound tourist market, the main tourist market position of Hong Kong, Macao and Taiwan is still stable, and the countries along "the Belt and Road" route have increased activity. There was a slight adjustment in the structure of foreign tourist market. In the inbound tourist market of foreigners, the top 17 tourist source countries of China were: Myanmar, Vietnam, South Korea, Japan, the United States, Russia, Mongolia, Malaysia, Philippines, Singapore, Canada, India, Thailand, Australia, Indonesia, Germany, the United Kingdom(Among them, Myanmar, Vietnam, Russia, Mongolia and India include the number of border Chinese). On the whole, the market of inbound tourists structure has shown an optimization trend. The activity in inbound tourism market of countries along "the Belt and Road" route is rising steadily.

\section{NATIONAL MOBILE PAYMENT INSTRUMENTS OF DIFFERENT COUNTRIES}

In China, there are online payment agencies represented by two Internet giants, Alipay and Tencent. Nowadays, people can live and shop without cash normally. Wechat payment, with 800 million monthly active users, is the mobile payment platform with the largest number of users in China. China mobile payment has not only changed the consumption mode of Chinese people, improved the "sense of gain" of Chinese people, but also has a high degree of attention and reputation abroad, so many countries and regions are competing to learn from China, and the leading position of China mobile payment is increasingly prominent. Cross-border business of Wechat payment has supported compliance access of 49 countries and regions, and transactions in 16 currencies and supported transactions in 16 currencies. Another mobile payment brand in China, Alipay, has already covered over 40 countries and regions worldwide, including hundreds of thousands of businesses worldwide.

According to the data, in 2017 , the person-time of outbound tourism of Chinese citizens exceeded 130 million, with a cost of US $\$ 115.29$ billion. China has been maintaining the position of the world's largest outbound tourist source country for many years. The French Tourism Development Agency estimated that China would become the second largest inbound tourist source country of France after the United States, with an estimation that the number of Chinese tourists France received would be 2.3 million in 2018 . With the footprint of Chinese tourists being all over the world, the pace of Chinese mobile payment enterprises to the world is also increasingly accelerating. According to WeChat payment and ant financial data, as of now, the two largest payment applications of WeChat payment and Alipay have landed in nearly 40 countries and regions. It has become a trend that governments around the world vigorously promote mobile payment. Canada, Britain, Singapore and European countries abolished large denomination currencies one after another. Denmark allowed retailers to reject cash payments and receive only mobile and bank card payments in 2016. In November of the same year, India's prime minister, Modi, abolished the banknote, which was also a typical event for the government to vigorously promote mobile payment. Countries and regions have launched mobile payment tools to provide consumers with payment convenience one after another(As shown in "Table II"). 
TABLE II. MOBILE PAYMENT INSTRUMENTS OF DIFFERENT COUNTRIES AND REGIONS

\begin{tabular}{|l|l|l|}
\hline No. & \multicolumn{1}{|c|}{$\begin{array}{c}\text { country / } \\
\text { region }\end{array}$} & \multicolumn{1}{|c|}{$\begin{array}{c}\text { name of payment } \\
\text { instrument }\end{array}$} \\
\hline 1 & U.S.A & $\begin{array}{l}\text { Paypal/Amazon } \\
\text { Payments/Google } \\
\text { wallet/Android pay/ } \\
\text { Apple pay }\end{array}$ \\
\hline 2 & Europe & Paypal/EasyEuro \\
\hline 3 & Japan & Paypay \\
\hline 4 & Holland & Google checout \\
\hline 5 & UK & $\begin{array}{l}\text { Money } \\
\text { worldpay }\end{array}$ \\
\hline 6 & Canada & AlertPay \\
\hline 7 & Australia & Paymate/Eway \\
\hline 8 & Hong Kong & Alipay \\
\hline 9 & India & PayTM \\
\hline
\end{tabular}

\section{PROBlems OF MOBILE PAYMENT FOR SHORT-TERM INBOUND TOURISM}

There are mainly the following ways of payment for personnel coming to China: the first is the traditional UnionPay credit card. This method is convenient and fast, but the payments can only be finisher while merchants hold the POS machines. It is suitable for small-scale and liquidity consumption such as buying bottles of water and snacks, but it is not convenient for taking a taxi. The second is new mobile payment, such as WeChat and Alipay. The third is cash. Many people who come to China say that because mobile payment is widely used in China, it's no exaggeration to say that buying a scallion in the vegetable market can "sweep it". Businesses avoid the trouble of saving money and drawing money in the bank, and they won't worrying about making mistakes in finding change, so they are more willing to receive the payment by scanning the code. When inbound tourists pay in cash, businessmen often say "no change, can't find it", which makes inbound tourists helpless. Domestic mobile payment is concentrated in WeChat and Alipay, and WeChat and Alipay first need to open communication accounts, then the communication accounts bind the bank accounts (bank cards). Short-term inbound tourists can obtain communication accounts according to their passports, but opening bank accounts needs to be handled at the counter. After the short-term tourism, tourists need to operate to release the binding of bank accounts and communication accounts, and then they need to go to the bank to cancel the accounts. The procedures of account opening and account closing, binding and cancellation are complex and time-consuming. In fact, many inbound tourists feel the trouble of mobile payment. We put forward the concept of all-for-one tourism, and constantly improve the tourists' feelings in the aspects of eating, housing, transportation, scenery, shopping and entertainment, and increase investment in improving the catering and accommodation environment, transportation facilities, building scenic spots and supporting facilities, renovating the shopping environment, and strengthening the education and training of tourism practitioners, and so on. If domestic consumers travel abroad, WeChat and Alipay will provide great convenience for payment. However, there are obvious deficiencies in mobile payment for inbound tourism. Neither inbound tourists nor merchants can feel the security and convenience of mobile payment, which not only affects the experience of inbound tourists, but also affects tourism revenue. From this point of view, the "last kilometer" of tourism economy has yet to be cleared up.

\section{ANALYSIS ON THE REASONS FOR THE PROBLEMS OF INBOUND TOURISM MOBILE PAYMENT}

\section{A. Impact of consumers' original payment habits}

The foreign credit card payment function is powerful, and the foreign consumers are used to the traditional credit card payment, who like to use visa, MasterCard and other credit cards. Taking the United States for an example, its credit card system has been built for a long time and its functions have been very complete. Most Americans think that it's easy to pay with bank card in the store, and mobile payment is not necessary at all. In fact, the reason why Americans hold credit cards so highly is that they can bring all kinds of benefits to users, which cannot be brought by cash, debit card and mobile payment. The U.S. credit system is perfect, which can provide price protection, shopping protection and other benefits. Banks provide reliable and very preferential services for credit cards users, such as free card opening, cash reward, using discount and so on. Americans use credit cards to consume, and each transaction has $2 \%-5 \%$ cashback or bonus points, which makes consumers feel like making money. This is the incomparable place of credit card that mobile payment doesn't have in this country. The United States has a strong credit card theft protection system. American credit cards do not need a password, and if the money is not expended by consumers' signing, the consumers can have zero responsibility. Many credit cards in the U.S. have insurance and claim functions. For example, in the event of an aircraft delay in booking a ticket by credit card, the card issuer will reimburse the cost of accommodation, catering and transportation during the delay period. Some cards offer extra insurance when consumers rent a car and they will get extra compensations in case of an accident. In the United States, from consumer shopping to expensive services such as hospital treatment, consumers are used to sending bills first and then paying. One of the advantages of non-instant payment is that it restricts the businesses to cheat consumers and promotes them to provide authentic and honest services. Paypal and Apple Pay of the United States are earlier than Alipay 
and WeChat payment, but the consumers feel that credit card is very convenient and don't have strong demand, and businesses have no drivers and are reluctant to invest in upgrading their devices. If Paypal and Apple Pay also establish a complete, convenient and profitable mobile payment system in accordance with the above advantages of the credit card system, and cultivate new payment habits of consumers, then the United States with a high penetration rate of smart phones will still be able to see the huge potential of mobile payment.

\section{B. Insufficient connection between financial policies and financial businesses}

Wechat registered overseas has only communication function, not financial function. Alipay registered overseas must bind domestic bank accounts to achieve financial functions, which is difficult for foreign consumers. Some foreign consumers adopt flexible methods, and bind the accounts of domestic relatives and friends, but their relatives and friends need to take some risks. If consumers consume on the platform of "Ant Credit Pay", once they fail to repay on time, the platform will deduct and recover money form the bound account. In addition, cross-border remittance between relatives and friends through banks is not only troublesome, but also has a high handling fee. Therefore, the method of binding domestic relatives and friends' bank cards is not feasible. The rapid development of internet technology provides conditions for cross-border mobile payment. The docking of mobile payment methods of various countries is not a problem in the field of electronic technology. The key lies in the docking of different countries' macro financial policies and the business interconnection of specific financial sectors. It is not so much a technical problem as a financial problem. Payment platforms in various countries also have their own standards, which need to be integrated and standardized. At present, the regulatory environment faced by cross-border payment is not easy. In the continuous compliance inspection, the business process mode may need re-combing and reassessment, and the expansion speed is also uncertain. On the one hand, the cross-border payment rate is higher than domestic mobile payment, but the frequency is lower than domestic mobile payment. On the other hand, different from domestic payment business, cross-border payment should not only need to meet the regulatory requirements of relevant departments of China, but also need to take into account the laws and regulations, financial supervision of local governments of foreign markets, and their human environment, which means that payment companies spend more in the layout of foreign payment market than of domestic payment market. How to improve the infrastructure and legal policy environment for mobile payment, improve the means and heighten the efficiency of payment, and then improve the contribution of payment to cross-border consumption even economic growth, is an unavoidable problem for China's decision-making departments and payment industry.

\section{CONCLUSION}

The experience in mobile payment of short-term bound tourism in Thailand. Thailand Agricultural Bank stipulates that small businesses in Thailand can apply for opening charging function of Alipay terminal when they open accounts in the bank. But there are few similar financial institutions in Thailand at present, and the business is still in the exploratory stage, with many small businesses who do not know how to open the function, so this function is still not popularized.

With "the Belt and Road" initiative from freehand brushwork to meticulous painting, China's opening to the outside world is deepening, and inbound tourism market gradually grows, and the inbound tourists is also becoming more and more diversified, and the market structure is gradually optimized. The countries along "the Belt and road" is the key development areas of China's inbound tourism market. In recent years, the order of source countries of inbound tourism are Korea, Vietnam, Japan, Burma, the United States, Russia, Mongolia, Malaysia, Philippines, Singapore, India, Thailand, Canada, Australia, Indonesia, Germany, Britain, France and so on. It can be seen that they are mainly the neighboring countries. First of all, there is a need for macro financial policy convergence between countries; second, the financial institutions need to connect with each other in business and improve the functions of payment tools. For example, based on the original payment business, more extended service products meeting customers' needs should be created and more extensive services should be provided, such as intelligent risk control by big data, anti-money laundering monitoring, account system, supply chain finance, installment payment, and face recognition, artificial intelligence, etc. In addition, it is also very important to gradually strengthen consumers' understanding and experience of mobile payment tools and cultivate consumers' new payment habits. "As the fastest-growing and largest market of e-commerce and mobile internet in the world, China should become and is fully capable to become the global center of epayment innovation." The Professor Fan Zhiyong of Renmin University of China said.

\section{References}

[1] Yeepay Research Institute. research report on the third-party cross-border payment industry in 2018. CIFNEWS, 2018.

[2] China Tourism Academy.Annual Report of China Inbound Tourism Development 2018. 2018-07-01. 
[3] Pan Chengrong. Strategy analysis of the third-party cross-border e-payment driving the development of cross-border Ecommerce $[\mathrm{J}]$. Practice in Foreign Economic Relations and Trade, 2018/3.

[4] Cao Junyi. Cross-border payments will become a "new blue ocean" for mobile payments[J].Financial Development Review, 2018/3.

[5] Yang Yongjie. Fierce competition between Chinese and foreign institutions in cross-border payment.Shanghai A Niu Information Technology Co., Ltd , wallstreetcn.com, 2018-11-19

[6] Payment and Clearing Association of China.Theory and practice of mobile payment[M]. China Financial Publishing House, 2015.8.

[7] Qin Chengde. Mobile Payment (second edition)[M]. Economy and Management Publishing House,2017.8. 